Електронне наукове фахове видання "Ефективна економіка" включено до переліку наукових фахових видань України з питань економіки

(Категорія «Б», Наказ Міністерства освіти і науки України від 11.07.2019 № 975) www.economy.nayka.com.ua | № 11, 2021 | 25.11.2021 p.

DOI: $10.32702 / 2307-2105-2021.11 .94$

УДК 334.02

Kh. Danylkiv

PhD in Economics, Associate Professor of the Department of Finance, Accounting and Analysis, Lviv Polytechnic National University, Ukraine, Lviv ORCID ID: 0000-0003-1283-6844

O. Serheiev

Senior Lecturer of the Department of Finance, Lviv Polytechnic National University, Ukraine, Lviv ORCID ID: 0000-0002-5918-9421

T. Havryliak

PhD in Economics,

Lecturer of the Highest Category of the Department of Accounting and Economic Disciplines,

Stryi Vocational College of Lviv National University of Nature Management, Ukraine, Stryi

ORCID ID: 0000-0002-4255-1658

\title{
FEATURES OF INNOVATIVE DEVELOPMENT OF SMALL ENTREPRENEURSHIP STRUCTURES IN FOREIGN COUNTRIES AND ITS USE IN UKRAINE
}

\author{
Х. П. Данилків, \\ к. е. н., доцент кафедри фінансів, обліку і аналізу, Національний університет \\ «Львівська політехніка», м. Львів, Украӥна \\ O. М. Сергеєв, \\ старший викладач кафедри фінансів, Начіональний університет \\ «Львівська політехніка», м. Львів, Україна \\ Т. С. Гавриляк,
}

к. е. н., викладач вищої категорії ичиклової комісї обліково-економічних дисциплін,

Стрийський фаховий коледж Львівського національного університету

природокористування, м. Стрий, Україна

\section{ОСОБЛИВОСТІ ІННОВАЦЙНОГО РОЗВИТКУ МАЛИХ ПІДПРИЕМНИЦЬКИХ СТРУКТУР У ЗАРУБІЖНИХ КРАЇНАХ ТА ЙОГО ВИКОРИСТАННЯ В УКРАЇНІ}

The innovation policy of the state has a great influence on the realization of the innovative activity of small business structures. The creation of an effective state mechanism for the dissemination and implementation of innovations and measures to protect and protect intellectual property rights to scientific and technological achievements is becoming the most important feature of the modern state. In countries with advanced market economies, small business structures occupy an honorable place in the economy, as well as receive appropriate support from governmental and nongovernmental institutions. At the same time, the task of the state is not limited to providing financial, technical, and other resources to small business structures on preferential terms, as well as to supporting private initiatives at any cost. The state is called primarily to create such an economic and legal climate that would allow small businesses not only to stay afloat but also to stay afloat. 
The purpose of the work is to study and generalize the foreign experience of innovative development of small business structures, as well as to find opportunities for its use in domestic practice.

The article describes the activities of state organizations for financial, informational, and advisory assistance to small businesses. The availability of credit programs for small businesses is considered. Tax incentives for state support of small businesses in economically developed countries are presented.

Having identified the features of the state regulatory policy of the world's leading countries in the field of innovative development of small businesses, conclusions were drawn on supporting this sector of the economy in Ukraine and identified possible ways of its effective innovation in the national economy. It is confirmed that the implementation of such changes will promote the development of innovative activities of small businesses, allow them to create a favorable business environment and conditions for innovative development, strengthen competitive advantages, ensure effective operation, create a solid foundation for modernization and integration of Ukraine into the European and world markets.

На реалізацію інновачійної діяльності малих підприємницьких структур має великий вплив інновачійна політика держави. Створення ефективного державного механізму поширення $i$ впровадження інновацій та заходів охорони й захисту прав інтелектуальної власності на науково-технічні досягнення стають найбільш важливою характеристикою сучасної держави. У країнах із розвиненою ринковою економікою малі підприємницькі структури посідають почесне місие в економічі, а також отримують належну підтримку з боку державних і недержавних інституцій. При цььому завдання держави не зводиться до того, аби на пільгових умовах надавати малим підприємницьким структурам фінансові, технічні та інші ресурси, а також підтримувати приватну ініціативу будь-якою ціною. Держава покликана в першу чергу створити такий економічний і правовий клімат, який дав би змогу малим підприємницьким структурам не тільки втриматися на плаву, але й зростати.

Метою роботи є вивчення й узагальнення зарубіжного досвіду інновачійного розвитку малих підприємницьких структур, а також пошук можливостей його використання у вітчизняній практиці.

У статті охарактеризовано діяльність державних організацій щодо фінансової, інформаційної та консультативної допомоги суб'єктам малого підприємництва. Розглянуто наявність кредитних програм для малих підприємнищьких структур. Наведено податкові стимули державної підтримки малого підприємництва в економічно розвинених країнах.

Визначивши особливості державної регуляторної політики провідних країн світу у галузі інноваційного розвитку малих підприємницьких структур сформовано висновки щуодо підтримки цього сектору економіки в Україні та виявив можливих шляхів його ефективного інновачійного функціонування в національній економіці. Підтверджено, щзо реалізація таких змін сприятиме розвитку інноваџійній діяльності суб'єктів малого підприємництва, дасть змогу сформувати для них сприятливе ділове середовище та умови інноваційного розвитку, зміцнить конкурентні переваги, забезпечить ефективне функціонування, створить надійний фундамент для модернізаиії та інтеграчії України до європейського і світового ринку.

Keywords: innovative development; small business structures; financial and credit support; economically advanced countries; world experience.

Ключові слава: інновачійний розвиток; малі підприємнищькі структури; фінансовокредитна підтримка; економічно розвинені краӥни; світовий досвід.

Statement of the problem in general and its connection with important scientific or practical tasks. Today, as never before, the question of supporting the innovative development of small businesses in our country arises. After all, many problems that prevent this sector from developing effectively have not been resolved in the 30 years of 
Ukraine's independence. These include the lack of development (and sometimes lack) of proper infrastructure, limited access to financial and credit institutions, the imperfection of the legal framework and the legal system, the lack of quality support from the state, the significant complexity of the bureaucracy, and so on. At the same time, with Ukraine's accession to the World Trade Organization, its acquisition of the status of a country with a market open» economy, domestic innovative small business is forced to learn to compete fiercely in the globalized economic space. Therefore, it is important to analyze the measures tested in the developed countries of the world and the developed tools to stimulate the innovative development of small business structures.

Considering that in economically advanced countries small business structures form the basis of the economy (according to the United Nations there are 53-55 million small businesses in the world, and small businesses employ about $50 \%$ of the population), as well as the fact that Such enterprises are the readiest to develop and implement innovations, and the parliament and parliament of these countries pay constant attention to supporting this sector of the economy. At the same time, the task of the state is not simply to transfer financial, technical, and other principles to small business structures, supporting them at any cost, but to create legal and economic conditions for their prosperity, ability to grow and develop in market conditions. Therefore, for the expansion of the small business sector and their sustainable development, it is very important to analyze the world experience of small businesses and justify the possibility of its use in Ukraine.

Analysis of recent research and publications, which initiated the solution of this problem and on which the author relies, the selection of previously unsolved parts of the general problem, which is the subject of this article. Research of problems of development of small business structures is carried out in scientific works of a number of Ukrainian and foreign researchers and economists, such as: Z.S. Varnalii, A.H. Butalov, O.B. Donets, P.T. Kolisnichenko, N.V. Tarasevych, O.V. Yakusheva, R. Kantylon, D. Rikardo, Dzh. Mil, Zh.-B. Sei, A. Smit, Y. Shumpeter, F. Khaiek, P. Druker. In most economic works, scientists try to study the experience of the functioning of this sector of the economy of foreign countries and transfer it to domestic enterprises.

Formulation of the goals of the article (task statement). Study and generalization of foreign experience of innovative development of small business structures, as well as search for opportunities for its use in domestic practice.

Presentation of the main material of the study with a full justification of the obtained scientific results. At present, in the developed countries of the world, effective tools for stimulating the innovative development of small business structures are being searched for and implemented, where considerable attention is paid to financial issues and credit instruments.

Let's take a closer look at them to study the potential possibilities of adapting the advanced foreign experience of stimulating the innovative development of small business structures in Ukraine.

The greatest scientific and practical interest is the US state small business development program, as American policy is one of the largest and most effective in the world. The state policy of promoting small innovative business in this country is aimed primarily at creating the necessary market infrastructure, as well as at forming a system of state and public support for the development of small businesses. By regulating the scientific and technical initiative of small businesses, the state not only invests its funds but also encourages financial, material and technical, and other forms of small business support. Thus, the share of small innovative businesses in the structure of the research and production complex is growing, its various connections with all sectors of the economy are expanding. Accordingly, the initiative form of organization of innovation activity is called - the form of support of small innovative entrepreneurship.

The policy of stimulating the innovation of small businesses is carried out at all levels of executive power from the federal government to the municipality. The possibilities of various executive bodies, as well as methods of stimulating small innovative entrepreneurship, are different. Therefore, it is advisable to limit the efforts of the federal government and local authorities.

The main influence of the federal government on the scientific and technical initiative of small businesses is the regulation of financial flows. According to the sources of funding, there are three areas: subsidies through federal agencies and departments; attracting private capital, and providing benefits. The federal government purposefully subsidizes small innovative businesses in the form of grants and contracts for the development of new products or technologies.

Among the complexes of measures to support small innovative entrepreneurship, «incubator programs» are of particular interest. The main purpose of «incubators is to support innovative small businesses, help entrepreneurs who want to, but can not start their own business. The latter receive the «incubator» preferential access to the production facilities of scientific equipment, venture capital funds, various services (in contrast to traditional industrial parks, where only production and office premises are leased). Accordingly, the demand for the services of «incubators» is presented mainly by small firms in science-intensive industries.

«Incubators» operate at the expense of states and local authorities; subsidies (often non-refundable) from the federal government; current fees of entrepreneurs who use these services; the percentage of the income of those wellfunctioning small companies that have left the «incubators; funds of universities and other educational institutions, industrial corporations, private organizers of their own «incubators» and donations.

An important area of state innovation policy for small innovative businesses, which is carried out at the federal level, is to attract private capital to finance it. It is sold mainly through wedding capital companies.

One of the most important channels of communication between small innovative and large firms is financial, which is realized through investments in independent venture funds that finance small innovative businesses, or through the organization of own subsidiary venture companies. In the latter case, corporations subsequently receive part of the 
profits of a small firm if its activities prove successful. Corporations often buy shares of small companies that interest them or enter into contracts to perform certain stages of innovation processes.

It is also worth noting that the US-based Federal Small Business Administration (SBA), which was established in 1953 and now has 14,000 branches nationwide, [7] helps and funds start-ups in-country through the activities of two key programs - SBIR and STTR.

SBIR (Small Business and Innovation Research) is a program that provides grants and other preferences to small businesses and start-up companies in their efforts to implement innovative research and development (Fig. 1). Since 1982, 11 federal agencies have been participating in it, formulating the priority topics of the GDR and the DCP and providing funding for the program. In particular, STTR (Small Business Technology Transfer) is a program extension of SBIR's work - help to bring a new product to market. The only condition for participation in the program is the joint activities of a scientific institution and business. Thus we have the effect of synergy between science and business. Funding for the program is from 500 thousand US dollars [9]. 


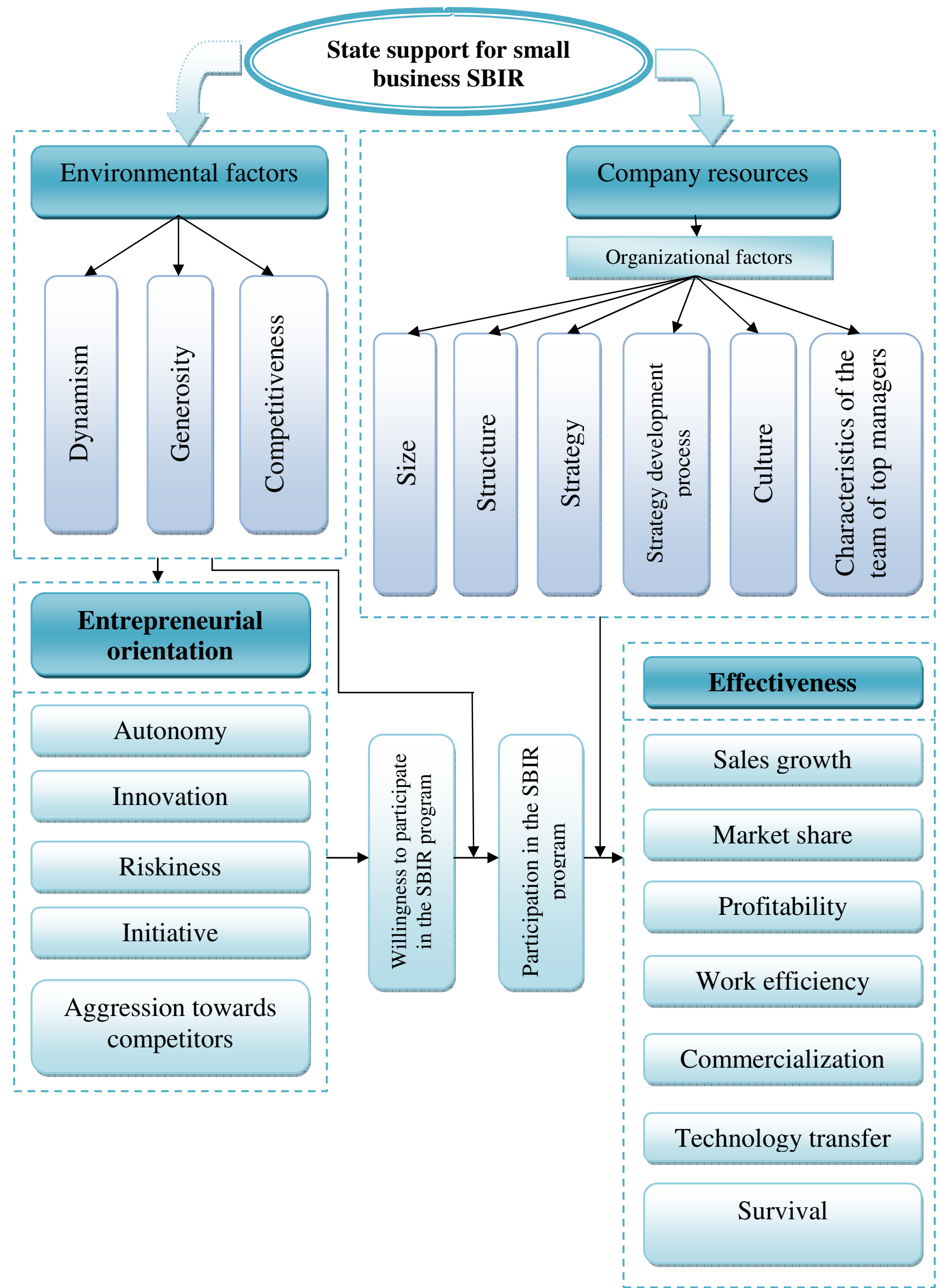

Fig. 1. Government support for small businesses through the SBIR program 
The uniqueness of the two programs is their availability for small existing and start-up companies in case of promising development for the implementation of technical solutions. The programs finance both the patenting stage and the stage of industrial introduction and further promotion of innovative products under the patent.

For more than 50 years, the agency has had many success stories, including the start-up stories of Bill Gates and Steve Jobs. The agency's funding is about $\$ 2$ billion at its peak. The selection of projects within the framework of the programs is carried out by teams consisting of many 1,400 expert volunteers - representatives of business, specialized government agencies, and technical specialists. Program funding and volunteering are in themselves a marketing ploy - so large companies learn about promising innovative businesses and look for ways to work with the winners of these programs (SBIR and STTR). This allows small companies to quickly commercialize their technology and grow rapidly [9].

Also, to ensure innovation, development of the small business sector, and the implementation of scientific and technical developments, the US Senate approved a bill to support small businesses worth $\$ 30$ billion [12]. The bill will not only support banks in providing loans but will also provide American entrepreneurs with various tax benefits. At the same time, Washington's main goal is to create new jobs and fight unemployment by stimulating small businesses.

In France, convinced that increasing the activity of small businesses affects the country's international competitiveness, special programs are implemented to help innovative enterprises, participating in their costs by providing subsidies, tax benefits, concessional loans, venture capital, and risk capital.

This country has developed its support system for various categories of small businesses. The first category includes ordinary small business structures, the support system of which provides for tax benefits: newly created small businesses are exempt from paying local taxes for 2 times, and joint-stock companies, reduced income tax and tax on the invested part of profits. The second category includes entrepreneurs who open enterprises in economically depressed areas. Their support system includes discounts and cancellations of payments to social security funds, and in some cases the payment of lifting. The third category - the unemployed who decided to open their own business. For them, the support system is implemented in tax exemptions for 3 days and a period of mandatory social benefits, as well as they, are issued special books with detachable checks, which can be used for management consultations, jurisprudence, accounting, and more. In addition, almost all small enterprises of six categories can receive soft loans, loans, and subsidies [5].

Also interesting is the French experience in approving new banking instruments to stimulate the innovative development of small businesses, namely, supporting technology transfer by providing loans of honor, which provide a loan for the creation of a small business (interest-free) provided to individuals who are honest and honest. as a capable organizer. The condition for loan repayment is the successful implementation of the project.

In France, there is also a regional network of training centers and organizations, technology transfer centers, and companies such as the already mentioned "incubators" of technology. Special joint-stock company SAFARIS (Societe Francaise de Garantie des Petités et Moyennes Enterprises), which includes 12 regional agencies and commercial banks, with a capital of almost 2 billion francs [8], assists small enterprises in the field of equipment modernization and international cooperation and also has a special fund for crediting their research projects, development of new products and bringing them to market. Thus, the state creates all conditions for the opening of new enterprises and uses all means to prevent their bankruptcy, including the purchase of enterprises by the National Agency for the Establishment of Enterprises in the event of bankruptcy.

The experience of the United Kingdom as a country with a deep historical tradition of doing business deserves considerable attention to an effective regulatory policy and strategy of financial and credit support for small innovative businesses. The state actively uses the instruments of budget, tax, and credit policy to stimulate this sector of the economy.

In general, support for small businesses in the UK is provided within the state budget, which is essentially a national program for the socio-economic development of the country. The budget envisages measures to improve the access of small businesses to financial practices, reduce the tax burden, minimize administrative barriers, and provide consulting and legal services [2].

The UK also pays close attention to the problems associated with lending to small businesses. The British are trying to use various methods to help increase the participation of commercial banks in lending to this sector of the economy. Therefore, the owners of small business structures, using the broad support of the state, have the opportunity to obtain in the form of various schemes preferential lending, ie a loan on very favorable terms.

Note that small businesses in the UK have significant tax benefits. In particular, they are exempt from income tax on funds allocated to information and telecommunications technologies, as well as part of the funds allocated to R\&D. In addition, the progressive scale of corporate income taxation creates relatively favorable conditions for small businesses with small profits [6].

Small innovative business in Singapore has the most profitable languages. A large positive field in the development of these enterprises is played, in particular, by the integration policy pursued by the state. It involves grouping such companies and providing them with the latest technology. The idea is quite simple and effective: one small business is often unable to afford a new high-tech production at the proper level. But for a group of such companies to beat it much easier. They share the entire production chain and achieve very good results.

The government is trying to make its small businesses internationally competitive because it is convinced that an uncompetitive entrepreneur makes the whole country uncompetitive. To support these enterprises, Singapore has created the only nationwide Spring agency, which consists of five departments and implements about 100 different 
programs to help entrepreneurs. The first deals with the development of the entrepreneurial potential of small companies, including branding and management improvement. Second - by providing services necessary for entrepreneurs for their activities (consulting, accounting, monitoring, and similar services) Employees of the third department help managers to pack their industry specifics. The agency's fourth department focuses on quality and standardization issues. Well, and the fifth - on issues of corporate development, including improving the structure of enterprises and training.

In Singapore, there is a public organization ASME (Association of Small \& Medium Enterprises), which unites, as the name implies, representatives of small and medium-sized businesses. ASME negotiates with government agencies, organizes business clubs, meetings, pieces of training for entrepreneurs and protects their interests. In addition, Singapore has implemented and implemented a large number of various soft loan programs, which include special loans, credit risk insurance, subsidies, training financing, and training of small businesses [8].

In Germany, small business has been strongly supported by the state for more than 30 years, as the government's economic policy constantly takes into account its interests. The overall goal of such support is to increase the efficiency and competitiveness of this sector of the economy. In the direction of implementation of this policy, two programs have been developed that facilitate the access of small business structures to capital and new technologies.

With the help of the first («Concept of development of scientific and technical policy about small and medium enterprises»), the financing of small businesses of the country is provided, the second program («Stimulating savings to start your own business») helps to open a business with projects «start-up». These programs contribute to the receipt of loans by small businesses for the development of their business with the use of low-interest rates on loans (5-8\%) and increase the term of use of credit funds to 5-15 years [8]. To implement and monitor the implementation of these programs, a special state body was created - the Credit Council for Reconstruction, which belongs to the federal government of Germany.

It should be noted that the German system provides not so much direct financing of small businesses, carried out with the help of loans and subsidies, as the stimulation of microfinance by providing funds to financial institutions working with small businesses. For this purpose, the financial group KfW Group was created, which is $80 \%$ owned by the Government of Germany [11]. It is both an analog of the local development bank, an export financing agency, and a credit organization specializing in financing more than 3 million small enterprises in Germany. In addition to financial and credit assistance, the German state also provides small businesses with active information support through the organization of comprehensive consultations and for entrepreneurs in all stages of business development.

Analyzing the policy of financial and credit support of small innovative entrepreneurship in different countries of the world, it is expedient to emphasize the effective principles of its formation and implementation by the Government of Japan.

In its policy to support small businesses, the Japanese government assumes that enterprises of this size are the most important actors in a market economy, as they create an effective competitive environment that allows intensifying the activities of other actors in the economic system (Fig. 2). That is why the state stimulation of a small innovative enterprise is carried out at all stages - registration, formation, and establishment. For this purpose, a whole system of various financial and credit instruments is used: soft loans and credits (general and target), tax benefits, technical and advisory assistance, information and computer services, training, etc. such assistance, based on legislation, is implemented through a system of public, mixed and private commercial and non-commercial organizations, including special centers for "growing" new innovative companies [8].

In Japan, the following three basic types of small business support centers have been established: «Venture business support centers - VBSC»; «Municipal Small Business Support Centers - MSBSC» and «Regional Small Business Support Centers - RSBSC» [10, p. 199]. Venture Entrepreneurship Support Centers gather information on innovation, effective business practices, and successful results in applying innovation to further disseminate progress. VCPP provides technical and methodological assistance to regional and municipal centers for small business support, as well as services for business project evaluation, corporate governance, analysis of prospects for the implementation of innovative developments, taxation, parenting, and other issues [8]. 
The state policy of small business development

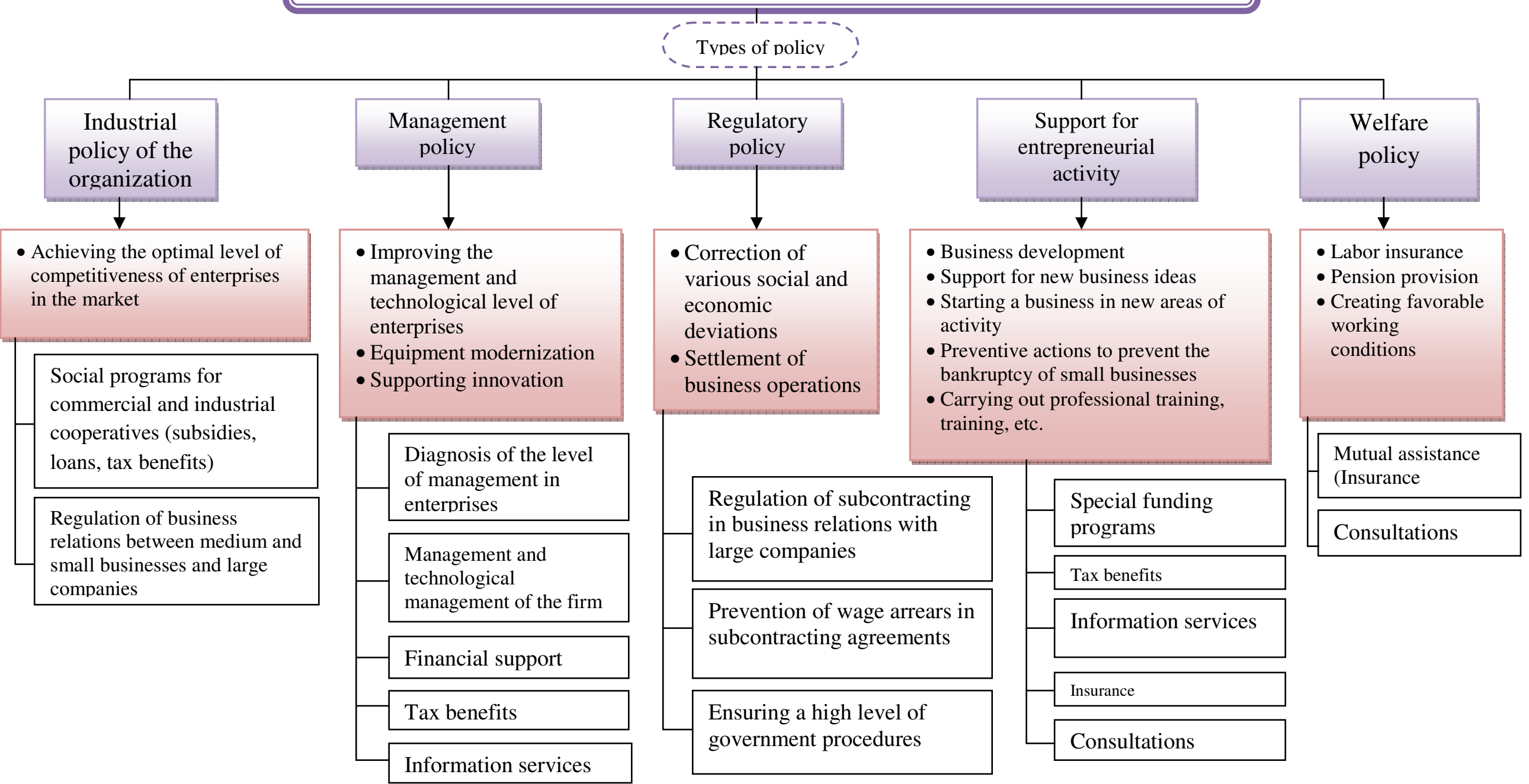

Fig. 2. The state policy of small business development in Japan 
To intensify innovation, comprehensive measures have been launched for financial, property, organizational, informational, and technical assistance at all levels of government. From the infrastructure of small business support, along with the creation of specialized structures to support venture business and innovation, measures were initiated to create credit and financial organizations that provide targeted funding for promising R\&D and innovative business structures. Support of technological innovations is carried out with the assistance of the national program Small Business Innovation Research» (SBI) [10, p. 202], very similar to a similar American program. The Japanese SBI program, to develop technological innovations in small businesses, attracts financial and technical capabilities of relevant ministries and agencies in the form of grants, soft loans, credit guarantees, and outsourcing services to assist new small firms in developing new technologies. further commercialization with the involvement of private capital (Fig. 3).

Another important example to follow is the People's Republic of China. China's small business can be called the country's new engine, thanks to the fact that small businesses produce the largest number of innovative products and technical inventions. Realizing this, the Chinese government is trying in various ways to promote the economic development of small innovative enterprises, improving the legislation created to regulate the economy and tax this sector of the economy.

In China, state funds for the support and development of small innovative businesses are active. Their main focus is to provide guarantees and collateral to obtain bank loans for the development of small businesses. To this end, the State Fund for the Development of Small and Medium-Sized Enterprises has been established, which helps protect the interests of small businesses in comparison with big businesses in all economic areas and provides certain tax benefits and additional financing for small businesses. Particular attention is paid to the possibility of rapid involvement of private venture capital in the small business sector on fairly favorable terms, taking into account preferential taxation. 


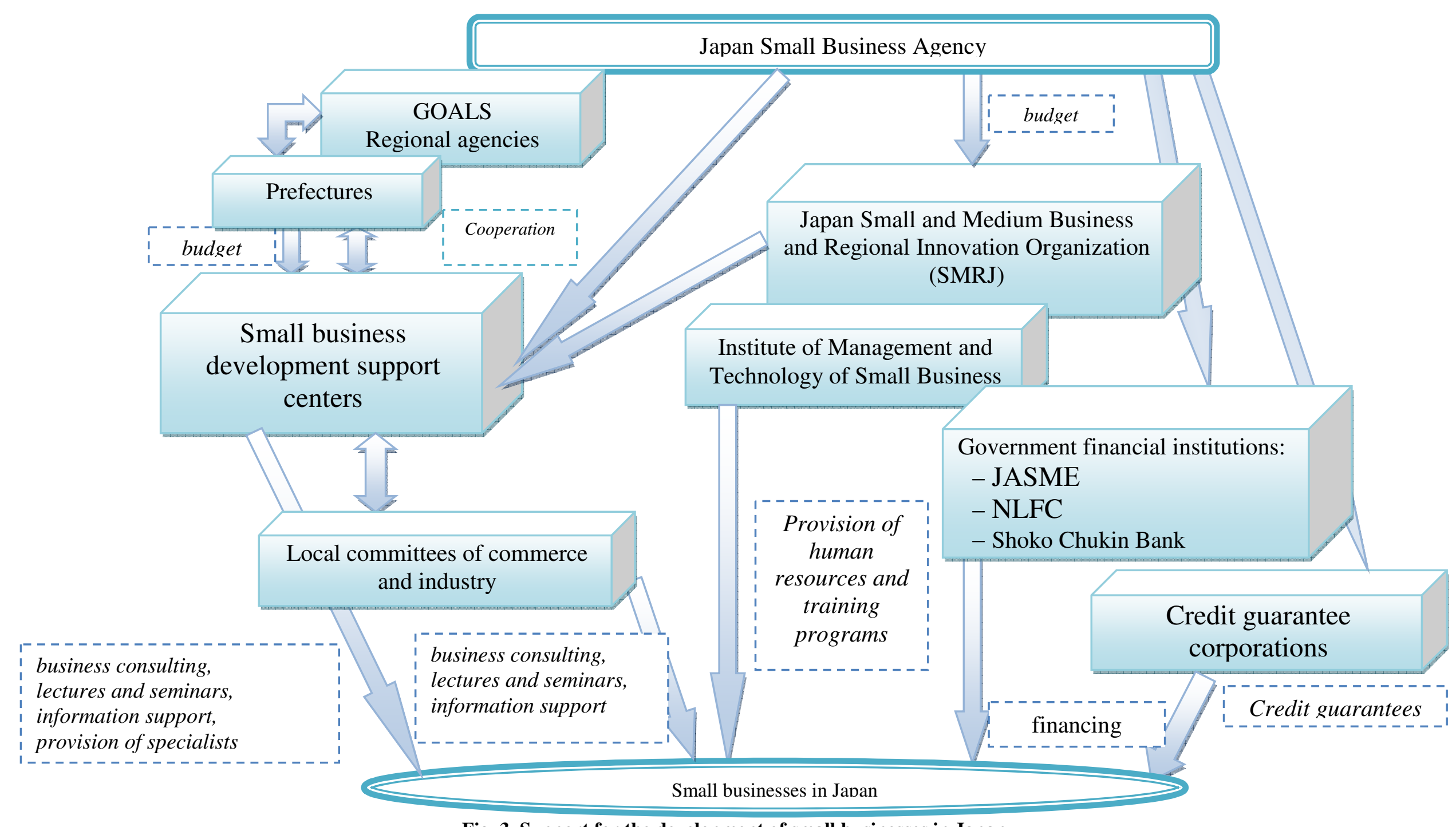

Fig. 3. Support for the development of small businesses in Japan 
Another important body that stimulates the development of China's economy is the state information service CSMEO, which was established in 2001. This service provides information consulting services to the population and entrepreneurs on small and medium-sized businesses through its website of the State Agency. The CSMEO network covers all regions of the PRC, which makes it possible to timely inform the population about the state of the labor market, changes in current legislation, the latest advances in science and technological inventions, the development, and the state of small businesses.

The state also forms regional specialized technical centers for the development of scientific and technical achievements in production, designed mainly for the technical renovation of small enterprises. 40 centers of services for the introduction of scientific and technical achievements, more than 600 centers of scientific and technical support for increasing the level of labor productivity, more than 100 enterprises - incubators of science-intensive technologies, more than 30 zones of science and technology development at universities, and more than 20 zones of scientific and technical development. technical achievements [1, p. 58].

Thus, innovative small businesses operate stably and efficiently in the developed countries of the world due to competent government support, which is a mutually conditioned pattern.

The analysis of the development of the small economy by types of economic activity shows that in this aspect the countries of the world focus on the permanent support of those activities of small business structures that are aimed at creating new products, ie existing in the manufacturing sector. If the first steps in the formation of a small business system in any country are concentrated around the benefits of the non-productive sphere, then, further, thanks to the purposeful policy of the state, a small economy gradually penetrates the sphere of material production and occupies an important place in the production of new goods [3, p. 41-42].

The key problem in Ukraine is the gap between the stated political goals and the actual implementation of political measures. Formal statements on the financial and credit needs for innovative development of a small enterprise are not supported by well-designed measures and, in particular, appropriate and effective mechanisms, programs, and framework conditions.

Conclusions from this study and prospects for further exploration in this direction. Conclusions from this study and prospects for further exploration in this direction. In our opinion, for small businesses to function effectively in the Ukrainian economy and bring positive innovation results, as it will beat it in the leading countries of the world, there is a need to strengthen the national innovation system and infrastructure for small innovative enterprises, including:

1. Reform the very structure of the banking sector. World experience shows that the banking sector, consisting of two parts - the central bank and commercial banks, is unable to provide medium-term and long-term lending to small customers. To do this, it is necessary to build a buffer between these two levels - the bank of the second level, a special credit institution, which at the expense of public funds will implement a lending regime to promote development, rather than commercial gain. And it will defeat this by co-financing commercial banks, not creating competition for them, but on the contrary, supporting their financial base.

Thus, a whole management chain is built: the state chooses priority areas, industries and economic sectors to promote their development - specialized credit institutions develop appropriate instruments of financial and credit regulation and distribute budgetary financial instruments, which are effectively managed by commercial banks. According to strategically defined priorities. This credit chain makes it possible to effectively carry out financial and credit regulation and to redistribute among all its members the traditionally high risks of small business lending, which commercial banks do not dare to take on while trying to minimize the risks.

2. To increase the legal protection of creditors and create an institutional motivation to involve commercial banks in lending to small businesses for their innovative development. Ukrainian banks do not dare to build credit relations with small businesses primarily due to insufficient protection of their rights, high risk, and significant cost of financial resources when lending to small businesses, which are more favorable than in the case of lending to large businesses. Given the limited own and borrowed financial resources, banks are more interested in cooperating with several large clients instead of many small ones, whose service costs are much higher. There are also no mechanisms for floating interest rates on long-term loans and levers for changing rates in cases of rising inflation. Despite the noticeable downward trend so far, the lending rates of commercial banks are still almost three times higher than the NBU discount rate.

Provide a set of measures to improve relations «bank-client». To reduce the administrative and operating costs of commercial banks, it is necessary to introduce a regime of preferential taxation of profits of commercial banks that lend to small businesses and reduce the requirements for mandatory reserves for banks that lend to small businesses. In Germany, tax benefits in the banking sector include special rates of depreciation deductions; the creation of tax-free profit reserves; investment allowances paid by tax authorities.

In our opinion, it is necessary to create mechanisms for providing state and non-state guarantees on loans with the acquisition of world experience of state financial support for the innovative development of small businesses. The network of mutual guarantee societies and guarantee funds will provide opportunities to mobilize assets and assets at the central and regional levels. To increase the level of small business confidence in banks, it is necessary to create special consulting institutions - credit bureaus.

3. Maintaining such a constructive financial instrument as financial leasing, which in its effectiveness is equivalent to long-term lending. Despite these trends and the capacity of the leasing services market, in Ukraine, there 
are many inconsistencies in the legal field of leasing and several reasons that hinder its development. The current government of Ukraine does not have a sound leasing strategy and action plan for its implementation. Measures taken by the Cabinet of Ministers of Ukraine today have a random character and do not give effective results, given that their development and implementation are engaged in many different government agencies and organizations [4, p. 167].

In our opinion, to solve the above-mentioned problems that complicate the efficiency and mobility of the regulation of the leasing services market in Ukraine, it is necessary to eliminate regulatory and legal obstacles at the legal level and in the mechanism of its financing, significantly improve organizational and economic conditions. effective mobilization and placement of financial assets of financial services market participants taking into account the interests of society, as well as accelerate the purposeful influence of public administration bodies on the economic interests of leasing participants to create conditions for leasing to perform its investment, production, and other functions, both microeconomic and at the macroeconomic level.

4. Credit unions in market countries are a very dynamic instrument of financial support for innovative development of small business and economic self-organization of the population, which is developing in Ukraine. Unfortunately, non-bank financial support specialists lack both experience and knowledge of modern technologies for lending to small businesses. And a new impetus for the development of the credit movement should provide a unified government policy to support non-bank financial institutions and a system of training for credit unions.

Therefore, in addition to procedures and technologies, credit unions need long-term and cheap financial resources, for which it is necessary to involve them in the implementation of state targeted microcredit programs for small businesses, programs of international financial organizations, and NBU programs in the mode of financing and target loans of commercial banks. The creation of liquidity support funds at credit union associations can also have an effect as a method in this matter.

5. The creation and development of an effective franchise network, due to the lack of knowledge and experience on this issue, do not allow the vast majority of domestic small businesses to properly use this powerful tool for innovative development.

According to the degree of development of the legal field, franchising relations in Ukraine are not legally supported, as there is currently no legal action to regulate such relations - it is under development. Relations between the subjects of franchising are regulated by separate sections of the Civil and Commercial Codes of Ukraine, which contain special rules on franchising (Chapter 75 of the Civil Code of Ukraine and Chapter 36 of the Civil Code of Ukraine) and mostly various regulatory documents and the franchisee concluded between the franchisee.

Therefore, a legislative initiative is needed to develop the Law of Ukraine «On Franchising» (which was recommended to be developed in 1997) and to make appropriate changes to existing regulations. This document will create transparent mechanisms for the formation and development of franchising, which will greatly contribute to the creation of national networks and international franchising. The practical development of franchise networks and their field in the innovative development of small businesses and the economy of Ukraine will largely depend on the quality and efficiency of this Law.

Therefore, the success of our country and its place in the global economy will directly depend on the level of innovative development of small businesses. Implementing the priority measures of innovation policy today, we invest in the future of Ukraine, form national competitive advantages, and create a solid foundation for modernization and integration of our country into European and world development.

\section{References.}

1. Vasilieva, L.M. (2009), "Development of small business in foreign countries", Derzhava ta rehiony. Seriia: Ekonomika ta pidpryiemnytstvo, vol. 7, pp. 56-60.

2. The official site of the Business press (2021), available at: http://www.businesspress.ru (Accessed 12 November 2021).

3. Dropa, Ya.B. and Danylkiv, Kh.P. (2011), "The role, dynamics and programs of state support for small business development in the leading countries of the world", Innovatsiina ekonomika, vol. 6, pp. 39-44.

4. Dropa, Ya.B. and Danylkiv, Kh.P. (2011), "The main sources of financial and credit development of small business", Ekonomichnyi prostir, vol. 52/2, pp. 161-173.

5. The official site of Small Business Business Plans \& Guides Portal (2021), "Small business in French", available at: http://www.openbusiness.ru/html_euro/france_open11.htm (Accessed 13 November 2021).

6. The official site of Internet Industry Library (2021), "Tax regulation in foreign countries", available at: http://www.i2r.ru (Accessed 13 November 2021).

7. The official site of the U.S. Small Business Administration (2021), available at: http://www.sba.gov (Accessed 12 November 2021).

8. The official site of Own Business Magazine (2021), available at: www.vlasbiz.net (Accessed 13 November 2021).

9. The official site of the Information Agency «LIGABiznesInform» (2021), available at: https://blog.liga.net/ (Accessed 12 November 2021).

10. Stoianova, M.M. (2009), "Adequacy of the state power of the small administrative unit (to the notice of Japan)", Ekonomichni innovatsii, vol. 38, pp. 196-203. 
11. Shepelev, S.E. "State support of small business abroad", available at: http://www.jurnal.org/articles/2008/ekon46.html (Accessed 10 November 2021).

12. Joseph Picard. "Small business aid bill stalls in Senate", International Business Times, available at: https://www.ibtimes.com/ (Accessed 14 November 2021).

Список літератури.

1. Васільєва Л. М. Розвиток малого підприємництва в зарубіжних країнах. Держава та регіони. Серія: Економіка та підприсмництво. 2009. № 7. С. 56-60.

2. Деловая пресса. URL: http://www.businesspress.ru (дата звернення 12.11.2021).

3. Дропа Я.Б., Данилків Х.П. Роль, динаміка та програми державної підтримки розвитку малого бізнесу в провідних країнах світу. Інновачійна економіка. 2011. № 6. С. 39-44.

4. Дропа Я.Б., Данилків Х.П. Основні джерела фінансово-кредитного розвитку малого підприємництва. Економічний простір. 2011. № 52/2. С. 161-173.

5. Офіційний сайт Small Business Plans \& Guides Portal. «Малий бізнес по-французьки». URL: http://www.openbusiness.ru/html_euro/france_open11.htm (дата звернення 13.11.2021).

6. Офіційний сайт Internet Industry Library. «Податкове регулювання в зарубіжних країнах». URL: http://www.i2r.ru (дата звернення 13.11.2021). 12.11.2021).

7. Офіційний сайт U.S. Small Business Administration. URL: http://www.sba.gov (дата звернення

8. Офіційний сайт журналу «Власний бізнес». URL: www.vlasbiz.net (дата звернення 13.11.2021).

9. Офіційний сайт Інформаційного агентства «ЛІГАБізнесІнформ». URL: https://blog.liga.net/ (дата звернення 12.11.2021).

10. Стоянова М.М. Вдосконалення державної підтримки малого підприємництва (досвід Японії). Економічні інновації. 2009. № 38. С. 196-203.

11. Шепелев C.Е. Государственная поддержка малого предпринимательства за рубежом. URL: http://www.jurnal.org/articles/2008/ekon46.html (дата звернення 10.11.2021).

12. Joseph Picard. Small business aid bill stalls in Senate. International business Times. URL: http://www.ibtimes.com/articles/39520/20100729/senate-small-business-banks.htm (дата звернення 14.11.2021).

Стаття надійила до редакичї 17.11.2021 p. 